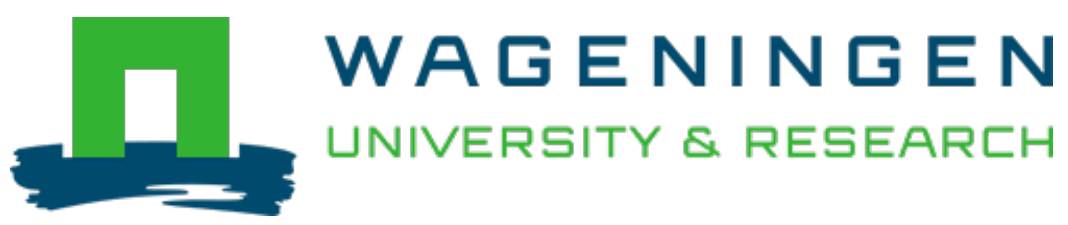

\title{
Tissue culture-induced DNA methylation polymorphisms in repetitive DNA of tomato calli and regenerated plants
}

\author{
Theoretical and Applied Genetics \\ Smulders, M.J.M.; Rus-Kortekaas, W.; Vosman, B. \\ https://doi.org/10.1007/BF00220938
}

This article is made publicly available in the institutional repository of Wageningen University and Research, under the terms of article $25 \mathrm{fa}$ of the Dutch Copyright Act, also known as the Amendment Taverne. This has been done with explicit consent by the author.

Article 25 fa states that the author of a short scientific work funded either wholly or partially by Dutch public funds is entitled to make that work publicly available for no consideration following a reasonable period of time after the work was first published, provided that clear reference is made to the source of the first publication of the work.

This publication is distributed under The Association of Universities in the Netherlands (VSNU) 'Article $25 \mathrm{fa}$ implementation' project. In this project research outputs of researchers employed by Dutch Universities that comply with the legal requirements of Article $25 \mathrm{fa}$ of the Dutch Copyright Act are distributed online and free of cost or other barriers in institutional repositories. Research outputs are distributed six months after their first online publication in the original published version and with proper attribution to the source of the original publication.

You are permitted to download and use the publication for personal purposes. All rights remain with the author(s) and / or copyright owner(s) of this work. Any use of the publication or parts of it other than authorised under article $25 \mathrm{fa}$ of the Dutch Copyright act is prohibited. Wageningen University \& Research and the author(s) of this publication shall not be held responsible or liable for any damages resulting from your (re)use of this publication.

For questions regarding the public availability of this article please contact openscience.library@wur.nl 


\section{Tissue culture-induced DNA methylation polymorphisms in repetitive DNA of tomato calli and regenerated plants}

\begin{abstract}
The propagation of plants through tissue culture can induce a variety of genetic and epigenetic changes. Variation in DNA methylation has been proposed as a mechanism that may explain at least a part of these changes. In the present study, the methylation of tomato callus DNA was compared with that of leaf DNA, from control or regenerated plants, at MspI/HpaII sites around five middlerepetitive sequences. Although the methylation of the internal cytosine in the recognition sequence CCGG varied from zero to nearly full methylation, depending on the probe used, no differences were found between callus and leaf DNA. For the external cytosine, small differences were revealed between leaf and callus DNA with two probes, but no polymorphisms were detected among DNA samples of calli or DNA samples of leaves of regenerated plants. When callus DNA cut with HindIII was studied with one of the probes, H9D9, most of the signal was found in highmolecular-weight DNA, as opposed to control leaf DNA where almost all the signal was in a fragment of $530 \mathrm{bp}$. Also, an extra fragment of $630 \mathrm{bp}$ was found in the callus DNA that was not present in control leaf DNA. Among leaves of plants regenerated from tissue culture, the 630 -bp fragment was found in 10 of 68 regenerated plants. This 630-bp fragment was present among progeny of only 4 of these 10 plants after selfing, i.e. it was partly inherited. In these cases, the fragment was not found in all progeny plants, indicating heterozygosity of the regenerated plants. The data are interpreted as indicating that a HindIII site becomes methylated in callus tissue, and that some of this methylation persists in regenerated plants and is partly transmitted to their progeny.
\end{abstract}

Key words Callus Epigenetic variation $\cdot$ Lycopersicon esculentum . Plant regeneration - Somaclonal variation

Communicated by H. F. Linskens

M. J. M. Smulders (区) - W. Rus-Kortekaas · B. Vosman Centre for Plant Breeding and Reproduction Research (CPRO-DLO), P.O. Box 16, NL-6700 AA Wageningen, The Netherlands

\section{Introduction}

Tissue-culture propagation can induce genetic and epigenetic changes in regenerated plants. Genetic changes have been coined 'somaclonal variation' by Larkin and Scowcroft (1981). This phenomenon has been reviewed extensively (e.g. Karp 1991), but insight into the process(es) leading to this variation is still limited. This is partly due to the variety of changes that can occur, ranging from point mutations to chromosome breakage and rearrangements (De Klerk 1990). In addition, it is also caused by the occurrence of changes that cannot be easily explained. These include mutations that are stable in a regenerated plant and during clonal propagation, but are not inherited by offspring; and changes that are inherited in selfed progeny, but disappear after crossing with a normal plant (Karp 1991).

Variation in DNA methylation has been proposed as a mechanism that may explain the wide range of changes that can occur after tissue-culture propagation, and might explain at least some of the peculiar changes described above (Kaeppler and Phillips 1993; Smulders et al. 1995). Methylation of DNA bases can lead to repression of gene expression (Matzke and Matzke 1991), so a change in methylation may mimic a point mutation in its phenotypic effect, namely the loss of a functional protein. An increase in DNA methylation can also lead to a more condensed chromatin structure (Lewis and Bird 1991), which is replicated late in the cell cycle. This would increase the chances of chromosome breakage due to chromatid segregation during mitosis if DNA replication is not yet completed (Kaeppler and Phillips 1993). In this way, changes in methylation may lead to deletions and inversions of parts of chromosomes.

The pattern of DNA methylation changes throughout the life cycle of a plant or animal (Brown 1989; Anderson et al. 1990). For instance, in tomato seeds $27.4 \%$ of the cytosine residues are methylated (mC). This drops to $20-21 \%$ in the young seedling. Mature leaves have $25.0 \% \mathrm{mC}$, but in pollen it is as low as $21.9 \%$ (Messeguer et al. 1991). 
From these data, it can be concluded that changes in overall methylation occur at least once in the life-cycle of a tomato plant. Also in wheat (Brown 1989; Brown et al. 1989) and pea (Watson et al. 1987) the methylation level drops when young seedlings develop. In mammals, it is known that the methylation pattern can be erased in the germ line (Holliday 1990). If this is also the case in plants, it may explain how a 'mutation' that consists of a change in methylation can be somatically stable but revert to wild-type in the progeny of a regenerated plant.

During the in vitro phase, the overall methylation percentage in maize is reduced (Kaeppler and Phillips 1993). In tomato, protoplasts contained $20.1 \% \mathrm{mC}$, which was comparable to young seedling tissues and is among the lowest percentage found (Messeguer et al. 1991). Anderson et al. (1990) mostly found lower methylation of rRNA genes in petunia calli, but some acquired high levels of methylation. The $5 s$-rRNA genes in soybean callus also became less methylated although re-methylation can occur during the next 2 years (Quemada et al. 1987). In carrot root explants, DNA methylation initially decreased but was increased after 2 weeks in the presence of auxin (LoSchiavo et al. 1989; Arnholdt-Schmidt et al. 1991; Arnholdt-Schmidt 1993). The pea cultivar "Dolce Provenza" showed an increase in methylation after regeneration (Cecchini et al. 1992). In contrast, CmCGG methylation in repetitive DNA did not change during 9 months of Cucumis melo callus cultures (Grisvard et al. 1990) and in some repetitive DNA sequences in tobacco, while methylation of 25s-rDNA sequences decreased somewhat in callus and plants regenerated from tissue culture (Vyskot et al. 1993).

Overall changes in methylation imply changes in the methylation status of some restriction sites. Studying such sites, frequent changes were found in barley anther culture-derived double haploids (Duvaux et al. 1993). Changes in DNA methylation were also frequent in maize callus, regenerated plants, and the progeny of such plants (Brown et al. 1991), and these methylation changes were stably inherited for two generations (Kaeppler and Phillips 1993). It was also found that some probes detected methylation changes more often than others, so perhaps methylation changes do not occur at random. Alternatively, some changes may be more stable than others. Maize is a monocotyledonous species in which structural changes are found at reasonable frequencies (De Klerk 1990; De Klerk and Bouman 1990; Karp 1991). In this species, the occurrence of transposon activity as a result of tissue culture (James and Stadler 1989; Peschke and Phillips 1991) is ex pected to contribute to this instability (Karp 1995).

The purpose of the present study was to analyze DNA methylation changes in tomato, a dicotyledonous species in which we were unable to detect any structural change in the DNA of calli and regenerated plants (Vosman et al. 1992; Rus-Kortekaas et al. 1994). The strategy employed was elaborated from the finding that leaves of regenerated plants do not show the DNA methylation pattern of the callus that they have been regenerated from, but have, in principle, switched back to the 'leaf' methylation pattern (Anderson et al. 1990). Because of this, we first selected probe/enzyme combinations that showed a different methylation pattern in callus compared to the leaves of control plants. Then, the leaves of regenerated plants and their progeny were screened for the presence of any residual callus-type methylation.

\section{Material and methods}

Plant material

Control plants were grown in the greenhouse from seeds of Lycopersicon esculentum cv Moneymaker (CGN-collection). First-generation regenerated (R1) plants were grown in the greenhouse after rooting of regenerated shoots (see below). Some second-generation regenerated (R2) plants were grown from seeds obtained by selfing selected R1 plants. Other R2 plants were grown from seeds of R1 plants that had been regenerated following the same protocol (Van den Bulk et al. 1990). Young leaves were harvested from 2 to 3-month-old plants, and stored at $-80^{\circ} \mathrm{C}$ until DNA extraction. Each DNA extraction was done using material from one plant.

For comparison, the same pieces of leaf, cotyledon and hypocotyl tissues as used for tissue culture were collected from seedlings grown in vitro, and stored at $-80^{\circ} \mathrm{C}$ until DNA extraction. Material from approximately $50-100$ seedlings was used for one DNA extraction.

\section{Tissue culture}

Tissue culture was started from seedlings grown aseptically for up to 5 weeks on MS-medium (Duchefa) supplemented with $2 \%$ sucrose and $0.65 \%$ agar (BBL) in $720-\mathrm{ml}$ glass jars in a growth room at $24^{\circ} \mathrm{C}$ and with $16 \mathrm{~h} \mathrm{day}^{-1}$ light (Philips fluorescent TL type $50 \mathrm{~W} 84 \mathrm{HF}$, maximum distance $30 \mathrm{~cm}$ ).

For the induction of regeneration, pieces of leaves, cotyledon and hypocotyl were cultured aseptically on MS-medium supplemented with $0.65 \%$ agar, $3 \%$ sucrose, $0.6 \mu \mathrm{M} \mathrm{IAA}$, and $4.6 \mu \mathrm{M}$ zeatin (Sigma)(Van den Bulk et al. 1990). After 6-9 weeks (leaf and cotyledon explants) or 9-12 weeks (hypocotyl explants), shoots were taken from the explants and rooted for $1-3$ weeks on MS-medium containing $0.65 \%$ agar and $2 \%$ sucrose. After rooting, the regenerated plants were transferred to the greenhouse and grown to maturity.

To obtain callus, the leaf, cotyledon and hypocotyl explants were cultured on MS medium supplemented with $0.65 \%$ agar, $3 \%$ sucrose, $11 \mu \mathrm{M}$ of 1 -naphthaleneacetic acid, and $4 \mu \mathrm{M}$ of benzylaminopurin. Callus was excised from cotyledon and hypocotyl explants after 6 weeks of culture and from leaf explants after 9 weeks. The callus material was subcultured at 3 -week intervals for a period of 9 weeks. Individual calli were stored at $-80^{\circ} \mathrm{C}$ until DNA extraction.

\section{DNA extraction and digestion}

DNA was extracted from calli and seedling organs according to Dellaporta et al. (1983). The procedure was modified by adding $1 \mathrm{M}$ $\mathrm{NaCl}$ to precipitate polysaccharides before the first DNA precipitation (Rus-Kortekaas et al. 1994). DNA of the R1 and R2 plants was extracted from young leaves according to the method of Bernatzky and Tanksley (1986) with modifications (Vosman et al. 1992).

For Southern hybridization, DNA was digested with the restriction endonucleases according to the manufacturer (Gibco/BRL), but with excess enzyme (10 U/ $\mu \mathrm{g}$ of DNA). All digestions were repeated after a phenol-chloroform extraction. After the restrictions, the DNA was separated on a $0.8 \%$ or $1.7 \%$ agarose gel and alkaline-blotted overnight onto Hybond $\mathrm{N}^{+}$(Amersham).

Probes

The repetitive probes used in this study were isolated from a bank of HindIII-digested total DNA from L. esculentum 83M7138 in 
Table 1 Summary of polymorphisms detected between DNA of callus and the leaves of control Moneymaker plants by the repetitive probes used in this study

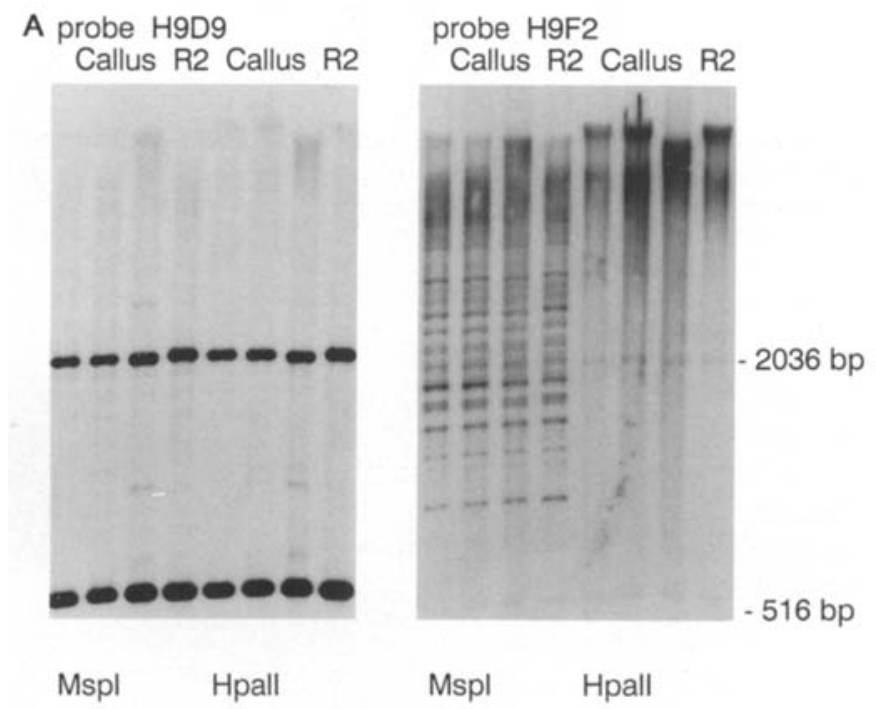

Fig. 1 MspI digests (left four lanes) and HpaIl digests (right four lanes) of DNA from three individual calli and from young leaves of one regenerated plant $(R 2)$. The calli had been induced on cotyledon, hypocotyl and leaf material. The samples were separated on $0.8 \%$ agarose and blotted onto Hybond $\mathrm{N}+$. This blot was hybridized with the probes H9D9, H9F2 (A), H9H6, and H9F5 (B). In B, stars mark some fragments that are specific for samples digested with $M s p I$, and arrows mark some fragments specific for callus DNA samples

pUC18 (a gift of P. Zabel, WAU, Wageningen, The Netherlands). The probes were selected for a medium-to-high copy number by hybridizing different dilutions of tomato genomic DNA to the inserts. As a reference, the same dilutions of genomic DNA were hybridized with the single-copy probe TG209 (insert size $950 \mathrm{bp}$ ). Some characteristics of the probes are listed in Table 1.

\section{Hybridizations}

The inserts were amplified by PCR using pUC primers, and randomprimed labelled as recommended by the supplier of the DNA labelling kit (USB biochemicals). Hybridizations were performed overnight at $65^{\circ} \mathrm{C}$ in a hybridization buffer consisting of $1 \mathrm{M} \mathrm{NaCl}$, $50 \mathrm{mM}$ Tris-HCl pH 7.5, $1 \%$ SDS, $10 \%$ dextran sulphate, and 0.1 $\mathrm{mg} / \mathrm{ml}$ salmon-sperm DNA (Sigma). Blots were washed at $65^{\circ} \mathrm{C}$ for $10 \mathrm{~min}$ in $2 \mathrm{SSC}$, followed by two high stringency washes of $30 \mathrm{~min}$ in $0.1 \mathrm{SSC}, 0.1 \% \mathrm{SDS}$, at $65^{\circ} \mathrm{C}$, and autoradiographed using KODAK

\section{B probe $\mathrm{H} 9 \mathrm{H} 6$} Callus R2 Callus R2
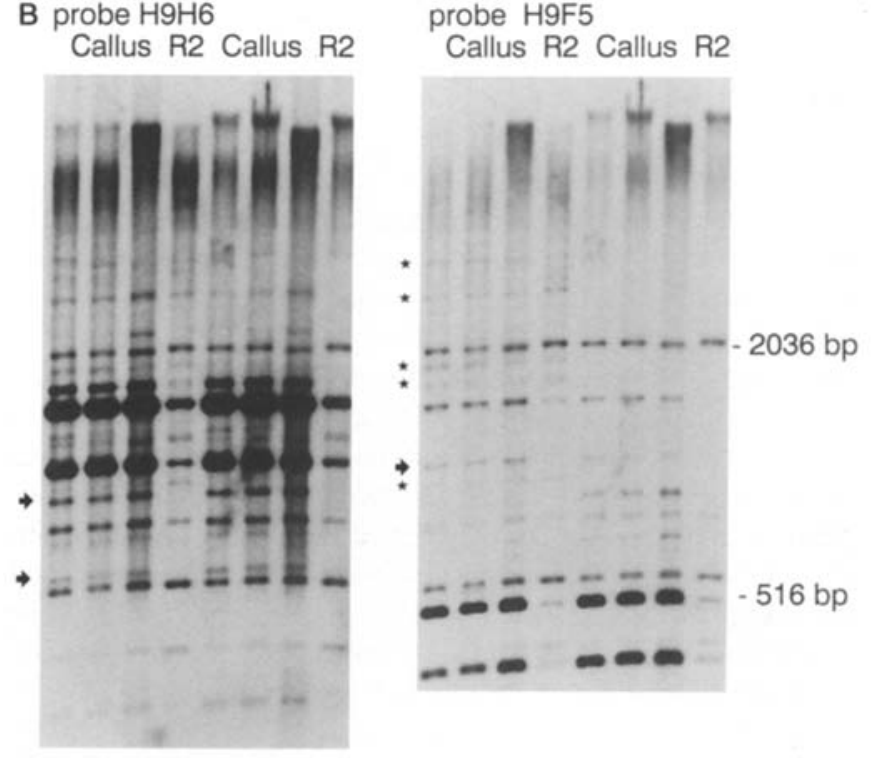

XAR-5 film at $-80^{\circ} \mathrm{C}$. For crucial comparisons among certain samples, the samples were processed together and placed on one blot.

\section{Results}

\section{Methylation differences at $M s p \mathbf{I} / H p a I I$ sites}

A number of repetitive probes were used to detect differences in DNA methylation between callus DNA and leaf DNA from control plants using $M s p I$ - and HpaII-digested DNA samples. With probe H9D9, no differences were found either between calli and leaf DNA or between the digestions with the two enzymes (Fig. 1). Apparently, there was no methylation of the internal cytosine at the CCGG sites made visible with this probe.

This was not so for all repetitive probes. When the same blot was hybridized with H9F2, the differences in banding patterns between the HpaII and $M s p \mathrm{I}$ digestions indicated almost full methylation at the second C of the CCGG sites. Again, the patterns of callus and leaf DNA were identical 
(Fig. 1). Using H9E12, the HpaII digestions were different from the $M s p$ I digestions, but only in a few bands, indicating some CmCGG methylation (data not shown). Differences between leaf and callus DNA in the methylation of the first cytosine (mCCGG) were found using probe H9H6, but no CmCGG methylation was detected (Fig. 1). Finally, probe H9F5 identified the presence of both types of methylation, and showed that mCCGG methylation differences were present between leaf and callus DNA (Fig. 1). These results are summarized in Table 1.

A number of these probes were subsequently used to see whether differences could be detected among leaf DNA samples from R1 and R2 plants digested with $M s p \mathrm{I}$ or HpaII. No difference in banding pattern was observed among $57 \mathrm{R} 1$ plants and $88 \mathrm{R} 2$ plants (data not shown).

Differences between callus and leaf DNA in HindIII digests

As reported previously (Vosman et al. 1992; Rus-Kortekaas et al. 1994), RFLPs among DNA samples of plants regenerated from tissue culture have also been searched for in our laboratory. To this end, leaf DNA from a number of R1 or R2 plants was digested with the restriction enzymes TaqI, EcoRI or HindIII and hybridized to probes that visualized a number of bands per lane, including the oligonucleotides (GATA) $)_{4}$ and (GACA) $)_{4}$ (Vosman et al. 1992; Arens et al. 1995) and the repetitive DNA probe H9H6. With the latter probe, no difference was detected among 258 DNA samples of calli, and among 165 samples of R2 plant leaf DNA (data not shown).

Surprisingly, when callus and control or R1 leaf DNA samples digested with HindIII were hybridized with H9D9, clear differences were visible between the callus sample on the one hand and the leaf samples on the other hand. First, in the leaf samples almost all of the signal was in a fragment of the expected length of $530 \mathrm{bp}$, but in the callus samples most of the signal was found in the high-molecular-weight area. Second, the callus samples contained an extra fragment of approximately $630 \mathrm{bp}$ that was not present in control leaf samples (Fig. 2). When the other repetitive probes were tested on HindIII-digested DNA from calli and leaves, all probes hybridized to the extra fragment in the calli samples, as well as to the 530 -bp fragment in all samples, but at a much lower intensity. When the probes were first restricted with HindIII to remove the PUC polylinker that was common to all probes, both bands disappeared from the hybridizations, except from those with probe H9D9 which were unaffected. Probe H9H6 visualized a band of approximately $1900 \mathrm{bp}$ in the callus samples that was not present in leaf DNA (Fig. 2; results summarized in Table 1). In the next experiment, attention was focussed on the extra 630-bp fragment visualized by probe H9D9.

In total, DNA samples of leaf material of 174 plants (12 control Moneymaker plants, $68 \mathrm{R} 1$ plants, and $94 \mathrm{R} 2$ plants), as well as DNA samples of 69 calli, were HindIIIdigested and hybridized with H9D9. The 630-bp fragment

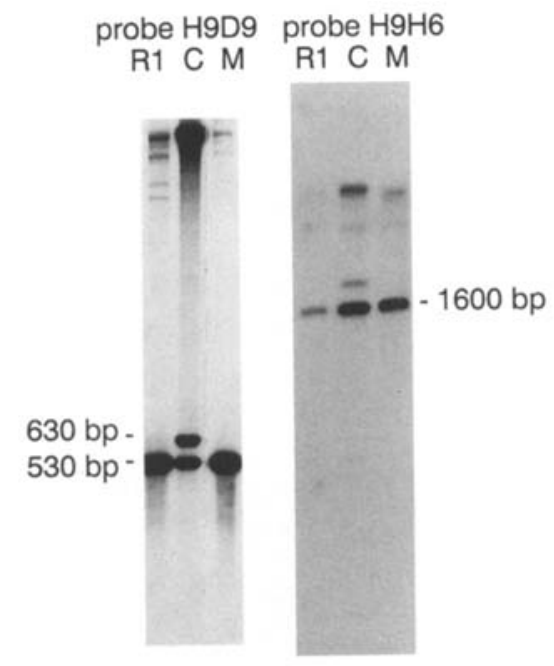

Fig. 2 HindIII digests of DNA from leaf material of a seed-propagated tomato $\mathrm{cv}$ Moneymaker plant $(M)$, one callus $(C)$, and leaves of one regenerated plant $(R I)$. The samples were separated on $0.8 \%$ agarose, and blotted onto Hybond $\mathrm{N}+$. The blots were hybridized with H9D9 and H9H6

was present in all callus samples, and the callus hybridization pattern could thus always be recognized. All leaf material from control Moneymaker plants, as well as the leaf samples of most regenerated plants, lacked the 630-bp band. However, a few regenerated plants did contain the 630 -bp fragment.

Differences in HindIII digests are not due to partial digestion

Our working hypothesis is that the extra $630 \mathrm{bp}$ fragment is the result of DNA methylation at one of the HindIII restriction sites flanking the 530-bp fragment in the callus DNA. HindIII is inhibited by $\mathrm{mC}$ (5-methylcytosine) and $\mathrm{mA}$ (5-methyladenine), i.e. it does not cut AAGmCTT (Huang et al. 1982) or mAAGCTT (McClelland and Nelson 1985). Although no isoschizomers are known for HindIII, four lines of indirect evidence indicate that the 630-bp fragment is not the result of partial digestion of all the callus DNA samples and a few leaf samples.

(1) The callus DNA extracted by our procedure could be restricted by several enzymes: TaqI, EcoR1, and Hinf. The hybridization patterns obtained with DNA restricted with any of these enzymes and the repetitive probes H9D9, H9E12, H9F2, H9F5 or H9H6, as well as oligonucleotide probes, were identical for callus and leaf samples (data not shown). Also MspI- and HpaII-restricted leaf and callus samples gave identical patterns with, for example, H9D9 (Fig. 1).

(2) When the same HindIII blots were hybridized with H9E12, H9F2 or H9F5, no differences were visible among the leaf and callus samples.

(3) When DNA was extracted from different organs of the same plant (root, hypocotyl, cotyledon, older and young 


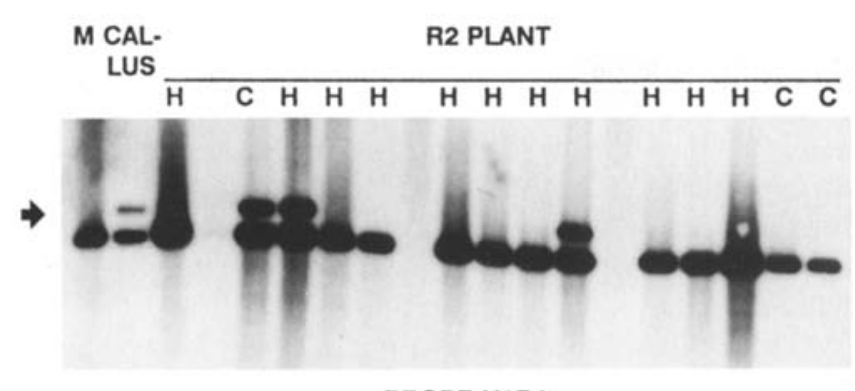

PROBE H9D9

Fig. 3 HindIII digests of DNA of leaf material of a seed-propagated tomato cv Moneymaker plant $(M)$, an individual callus, and a number of R2 plants derived from cotyledon $(C)$ or hypocotyl $(H)$ explants. Blot hybridized with H9D9. The arrow indicates the extra 630 -bp fragment that can be found in the callus samples and in some of the $R 2$ plants

Table 2 Presence of the extra 630-bp fragment in HindIII-restricted DNA from direct regenerants (R1) and the R2 progeny of selected R1 plants, hybridized with H9D9

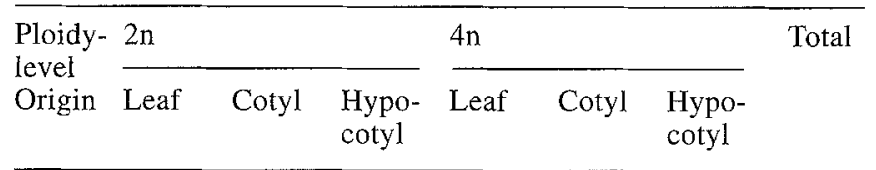

\begin{tabular}{|c|c|c|c|c|c|c|c|}
\hline \multirow{3}{*}{$\begin{array}{l}-^{\mathrm{a}} \\
+\end{array}$} & \multicolumn{7}{|c|}{ R1 plants } \\
\hline & 24 & 26 & 0 & 2 & 5 & 1 & \\
\hline & $1^{\mathrm{b}}$ & 0 & 0 & 0 & 0 & 9 & 10 \\
\hline \multirow[t]{2}{*}{ Total } & 25 & 26 & 0 & 2 & 5 & 10 & 68 \\
\hline & \multicolumn{7}{|c|}{$\mathrm{R} 2$ progeny of ' + ' $\mathrm{R} 1$ plants $^{\circ}$} \\
\hline- & 1 & 0 & 0 & 0 & 0 & 23 & 24 \\
\hline+ & 2 & 0 & 0 & 0 & 0 & $4^{\mathrm{d}}$ & 6 \\
\hline
\end{tabular}

leaves of tomato seedlings) and restricted with HindIII, $E c o$ R1, or $M s p$ I, the hybridizations with H9D9 yielded one pattern for each enzyme, irrespective of the tissue used (data not shown). Conversely, some leaf samples of R1 and $\mathrm{R} 2$ regenerated plants (see below) did show the extra band. Therefore, the presence of an extra fragment does not correlate with a certain type of tissue.

(4) Treating callus DNA samples with proteinase K before HindIII restriction did not remove the 630-bp fragment from the hybridization pattern obtained with H9D9, indicating no interference by proteins (data not shown).

Variation detected among regenerated plants and their progeny

Among the $68 \mathrm{R} 1$ plants that were studied with probe H9D9 using HindIII-digested DNA, ten plants (15\%) showed an extra fragment (Table 2). In nine of the ten plants, the 630-bp fragment characteristic of callus samples was found (examples are shown in Fig. 3). These nine plants were all tetraploids regenerated from hypocotyl tissue. One diploid plant regenerated from leaf tissue also showed a polymorphism, but this sample contained a smaller fragment of approximately $450 \mathrm{bp}$ (data not shown).

To study the inheritance of the changes, the R1 plants were allowed to self-pollinate and set seed. Three R2 seedlings of each of the ten R1 plants that had shown a polymorphism were grown in the greenhouse. After 2 months, when these seedling plants had developed at least two mature leaves, DNA was isolated from the young leaves, restricted with HindIII, and analyzed with probe H9D9. The extra fragment was found among the progeny of 3 of the 9 plants regenerated from hypocotyl tissue: in one case in 2 of the 3 R2 plants of the same parent, and in the other cases in only 1 of $3 \mathrm{R} 2$ plants. For the plant regenerated from leaf tissue, two progeny plants showed a polymorphism. Surprisingly, this was the same $630 \mathrm{bp}$ fragment as in the other plants. It is, therefore, not clear what has caused the 450-bp band in the regenerated plant.

Thus, four of the ten progeny lines were found to contain a polymorphism. The finding that progeny were recovered with and without the extra fragment is consistent with the fragment being present in the tissue culture-derived R1 plants in a heterozygous form. Theoretically, in the case of a tetraploid plant with only one of the four chromatids changed, random testing of three progeny plants reduces the chance of not detecting the polymorphism to $3.1 \%$. From this it was calculated that, among the six negative progenies, one positive progeny line may have remained unnoticed $(P>0.05)$. Thus, the inheritance of the fragment to the second generation can be estimated to be $40-50 \%$. The ten control Moneymaker plants, and the majority of the R1 and R2 plants, did not show the polymorphism. If we assume that the polymorphism is indeed the result of tissue-culture propagation, and will not appear in progeny of the 59 plants that did not show the polymorphism themselves, then the overall frequency of this polymorphism in the second-generation plants regenerated from tissue culture is $6-7 \%$.

Frequency of the polymorphisms in a population of seedlings of regenerated plants

The presence of the 630-bp fragment was also studied in the progeny of regenerated plants from a separate experiment on somaclonal variation. From seeds obtained by selfing a large number of R1 plants (Van den Bulk et al. 1990) a selection was made that also included seeds of (relatively rare) diploid plants regenerated from hypocotyl tissue. Also, a small number of lines was included that carried a tissue culture-induced morphological mutation. In this experiment, only one R2 plant of each of the parent R1 lines was tested.

When the DNA of these R2 plants was compared using probe H9D9, it was found that 5 of 64 plants ( $8 \%$ ) had the extra 630-bp fragment (Table 3 ). This compares well with 
Table 3 Presence of the extra 630-bp fragment in HindIII-restricted DNA from R2 plants, hybridized with H9D9

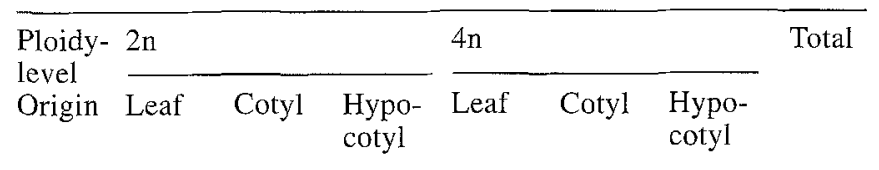

\begin{tabular}{|c|c|c|c|c|c|c|c|}
\hline \multirow[b]{2}{*}{$-{ }^{b}$} & \multicolumn{7}{|c|}{ R2 plants $^{\mathrm{a}}$} \\
\hline & 20 & 15 & 13 & 1 & 3 & 7 & 59 \\
\hline+ & 1 & 1 & 2 & 0 & 1 & 0 & 5 \\
\hline Total & 21 & 16 & 15 & 1 & 4 & 7 & 64 \\
\hline
\end{tabular}

a Every R2 plant originated from a different regenerated plant

b -, fragment absent; + , fragment present

the $6-7 \%$ found in the previous experiment. In one line carrying the recessive mutation 'entire leaf' (Van den Bulk et al. 1990; present in heterozygous form in the R1 parent, since some R2 plants showed the mutation but others did not), the polymorphism was found in one progeny plant that did not show the mutation.

Remarkably, no polymorphisms were present in tetraploid hypocotyl-derived lines. However, three plants per tetraploid parent must be tested to reduce the chance of not detecting a polymorphism that was transmitted from one of the four chromatids of each selfed parent to $5 \%$ or less. Therefore, the results leave the possibility open $(P>0.05)$ that 2 of the 7 tetraploid hypocotyl-derived R2 lines did produce progeny that contained the band. The frequencies of the fragment among the three explant sources in this experiment, or between diploid and tetraploid plants, were too low to draw conclusions.

\section{Discussion}

In this paper, the effect of tissue culture on DNA methylation in tomato was studied using five repetitive probes (Table 1). In leaf DNA, the methylation of cytosines, as detected by the isoschizomers $M s p \mathrm{I}$ and $H p a \mathrm{II}$, varied widely, from no detectable methylation to complete methylation at nearly all sites screened. Only small differences in methylation were found between callus and leaf DNA (Fig. 1).

When these probes were used on DNA samples digested with HindIII, polymorphisms were observed between control leaf and callus DNA with two probes, H9D9 and H9H6. The differences between the two tissues were most pronounced with the former probe: while in leaf DNA most of the signal was present in a 530-bp fragment, in callus DNA most of the signal was in the high-molecular-weight fraction, and an extra fragment of $630 \mathrm{bp}$ appeared. This extra fragment was alo present in a number of $\mathrm{R} 1$ and $\mathrm{R} 2$ plants. Several measures have been taken to ensure complete digestion of the DNA with HindIII. Therefore, we assume that at these HindUI sites, differential methylation is being measured. It is known that HindIII is inhibited by methylated adenine and cytosine (Huang et al. 1982; McClelland and Nelson 1985).

The notion that HindIII sites in plants can be methylated is supported by other reports. First, although the simplified view is that 5-methyl-cytosine is only present in CG dinucleotides and CNG di- and tri-nucleotides (in plants), Gruenbaum et al. (1981) showed for wheat-germ DNA that, while $\mathrm{mC}$ was present in $>80 \%$ of the $\mathrm{CG}, \mathrm{CAG}$ and CTG sequences, it was also present in $19 \%$ each of CA and CT, along with $7 \%$ of CC. This correlates well with the specificity of DNA methylases (Sano et al. 1983; Adams et al. 1990). In Petunia, $\mathrm{mC}$ was found outside ( $\mathrm{G}$ and $\mathrm{CNG}$ sequences (Meyer et al. 1994). Second, other modified bases have also been found in plant cells, including $\mathrm{N}^{6}$ methyladenine (Ngernprasirtsiri et al. 1988, 1989; Vanyushin and Kirnos 1988; Dhar et al. 1990, Kobayashi et al. 1990). Whether the methylation that is seen here at HindIII sites is adenosine methylation or cytosine methylation in sequences other than $\mathrm{CG}$ or $\mathrm{CNG}$, remains to be determined.

Some reports also point at the methylation of HindIII sites in plants. Müller et al. (1990) observed polymorphisms among rice plants regenerated from a single callus when the DNA was restricted with HindIII. The plants that had shown polymorphisms also showed digestion with $D p n I$, indicating the presence of $\mathrm{N}^{6}$-methyladenine in these plants. Brown et al. (1991) found such large differences among maize callus cultures after a HindIII digest (other enzymes were not used) that the authors wondered how it was possible that the majority of the regenerated plants had 'reverted' to the parental genotype. Such reversion is what would be expected if the enzyme detected callus-specific methylation, i.e. methylation of specific bases that are not usually methylated in leaf DNA.

In the present study, most of the signal from probe H9D9 in callus DNA was in the high-molecular-weight fraction, indicating methylation of both HindIII sites flanking the 530 -bp fragment in a large number of copies. The occurrence of a 630-bp fragment may be caused by methylation of one HindIII site flanking the 530-bp fragment, with another, unmethylated, HindIII site approximately $100 \mathrm{bp}$ away. This extra fragment of $630 \mathrm{bp}$ was also present in $13 \%$ of the regenerated plants (Table 2). In these plants, the fragment may therefore be considered as a remnant of the de novo methylation that occurs during the callus phase of tissue culture, which failed to be removed in some regenerated plants. In regenerated maize plants (Kaeppler and Phillips 1993) only decreases in methylation were detected. In barley double-haploids, however, both increase and decrease of methylation was found (Duvaux et al. 1993), while in carrot root explants de novo methylation took place in the presence of auxin (Arnholdt-Schmidt 1993).

The methylation at CCGG sites around the probe sequences is not changed. At first sight, this may seem to indicate that the methylation at the HindIII sites is changed very specifically. However, if a different methylase is involved, the change in methylation need not be subtle or local. 
Few studies have determined the inheritance of methylation changes induced by tissue culture. In maize, methylation changes were $100 \%$ inherited in two generations of progeny plants (Kaeppler and Phillips 1993). In tobacco, 5-azacytidine-induced hypomethylation was maintained during plant regeneration (Koukalová et al. 1994). In our study, the $630-b p$ fragment is only present in $40-50 \%$ of the offspring of those R1 plants that contained the band. Therefore, the fragment was only partly inherited by the progeny lines. In all, 6-8\% of the second generation offspring lines contained the extra band.

Can the polymorphism found here among regenerants from tissue culture, and their progeny, be used to increase our knowledge about the factors influencing the occurrence of these changes in tissue culture? At first sight, a 6-8\% variation seems quite high; however, the plants and lines showing the polymorphism were scattered over different explant sources, different periods of tissue culture before appearance of the shoots, and different ploidy levels. With respect to the origin of the explant, 9 of 10 polymorphisms in the R1 plants were found in tetraploid shoots regenerated on hypocotyl explants (Table 2). The hypocotyl regenerants, which were all tetraploid, were among the last shoots to be transferred from the explants to the rooting medium: after 12 weeks of culture compared to 9 weeks for the majority of shoots from cotyledon and leaf explants. However, this may not be taken as a longer period of undifferentiated cell division, since the first development of leaf-like structures on the hypocotyl explants had been visible at an earlier stage than on the explants from other sources. Only the outgrowth of shoots from these structures was very slow, possibly related to the fact that they were tetraploid.

In the second experiment with R2 plants (Table 3), the R1 shoots had been taken from the explants after 6 weeks and after 12 weeks of culture (Van den Bulk et al. 1990). The R2 seeds used here were evenly taken from the 6- and 12 -weeks groups, but 4 of the 5 lines showing a polymorphism (Table 3) were derived from the 6-weeks group. The results therefore do not indicate that longer periods of tissue culture induce more variation in DNA methylation among regenerant shoots. Also Van den Bulk et al. (1990), using the same material, did not find any effect of the length of the tissue-culture period on morphological mutations.

What does this mean for the phenomenon of variation induced by tissue culture? Although the frequency of fragment polymorphisms may be high compared to frequency of structural changes in the DNA [which was (over)estimated for morphological mutations, using the same material, to be $1.2 \times 10^{-4}$; Van den Bulk et al. 1990], it is still low when the factors that may influence the frequency are studied. In order to gain more insight into causes and consequences, it will therefore be necessary to study the relationship between DNA methylation and changes induced during tissue culture in specific cases with a very limited number of variables. For this, those processes that show a high frequency of specific change(s) may be the most promising; for instance, the relationship between DNA methylation and vitrification.
Acknowledgements We thank Dr. P. Zabel for his gift of the repetitive probes, R. Verwoert for nursing the plants, and Drs. A. Pereira and $C$. van der Wiel for critical reading of the manuscript.

\section{References}

Adams RLP, Bryans M, Rinaldi A, Smart A, Yesufu HMI (1990) Eukaryotic DNA methylases and their use for in vitro methylation. Phil Trans R Soc Lond B 326:189-198

Anderson S, Lewis-Smith AC, Smith SM (1990) Methylation of ribosomal RNA genes in Petunia hybrida plants, callus cultures and regenerated shoots. Plant Cell Rep 8:554-557

Arens P, Odinot P, van Heusden AW, Lindhout P, Vosman B (1995) GATA- and GACA-repeats are not evenly distributed throughout the tomato genome. Genome 38: 84-90

Arnholdt-Schmitt B (1993) Rapid changes in amplification and methylation pattern of genomic DNA in cultured carrot root explants (Daucus carota L.). Theor Appl Genet 85:793-800

Arnholdt-Schmitt B, Holzapfel B, Schillinger A, Neumann K-H (1991) Variable methylation and differential replication of genomic DNA in cultured carrot root explants during growth induction as influenced by hormonal treatments. Theor Appl Genet $82: 283-288$

Bernatzky R, Tanksley SD (1986) Genetics of actin-related sequences in tomato. Theor Appl Genet 72:314-321

Brown PTH (1989) DNA methylation in plants and its role in tissue culture. Genome 31:717-729

Brown PTH, Yoneyama K, Lörz H (1989) An investigation into the role of 5-azacytidine in tissue culture. Theor Appl Genet $78: 321-328$

Brown PTH, Göbel E, Lörz H (1991) RFLP analysis of Zea mays callus cultures and their regenerated plants. Theor Appl Genet $81: 227-232$

Cecchini E, Natali L, Cavallini A, Durante M (1992) DNA variations in regenerant plants of pea (Pisum sativum L.). Theor Appl Genet 84:874-879

De Klerk G-J (1990) How to measure somaclonal variation. Acta Bot Neerl 39:129-144

De Klerk G-J, Bouman H (1990) Measurement of somaclonal variation. In: De Jong $J$ (ed) Integration of in vitro techniques in ornamental plant breeding. Pudoc, Wageningen, pp 18-24

Dellaporta SL, Wood J, Hicks JB (1983) A plant molecular DNA minipreparation. Version II. Plant Mol Biol Rep 1:19-21

Dhar MS, Pethe VV, Gupta VS, Ranjekar PK (1990) Predominance and tissue specificity of adenine methylation in rice. Theor Appl Genet 80:402-408

Duvaux P, Kilian A, Kleinhofs A (1993) Anther culture and Hordeum bulbosum-derived barley double haploids: mutations and methylation. Mol Gen Genet 241:674-679

Grisvard J, Sevignac M, Chateau M, Branchard M (1990) Changes in a repetitive DNA sequence during callus culture of Cucumis melo. Plant Sci 72:81-91

Gruenbaum Y, Naveh-Many T, Cedar H, Razin A (1981) Sequence specificity of methylation in higher-plant DNA. Nature 292:860-862

Holliday R (1990) DNA methylation and epigenetic inheritance. Phil Trans R Soc Lond B 326:329-338

Huang L-H, Farnet CM, Ehrlich KC, Ehrlich M (1982) Digestion of highly modified bacteriophage DNA by restriction endonucleases. Nucleic Acids Res 10:1579-1591

James MG, Stadler J (1989) Molecular characterization of mutator systems in maize embryogenic callus cultures indicates mu-element activity in vitro. Theor Appl Genet 77:383-394

Kaeppler SM, Phillips RL (1993) Tissue culture-induced DNA methylation variation in maize. Proc Natl Acad Sci USA 90:8773-8776.

Karp A (1991) On the current understanding of somaclonal variation. Oxford Surveys Plant Mol Cell Biol 7:1-58.

Karp A (1995) Somaclonal variation as a tool for crop improvement. In: The methodology of plant genetic manipulation: criteria for 
decision making. Proceedings of the Eucarpia Conference, Cork, Ireland, 1994 (in press)

Kobayashi H, Ngernprasirtsiri J, Akazawa T (1990) Transcriptional regulation and DNA methylation in plastids during transitional conversion of chloroplasts to chromoplasts. EMBO J 9:307-313

Koukalová B, Kuhrova V, Vyskot B, Široký J, Bezděk M (1994) Maintenance of the induced hypomethylated state of tobacco nuclear repetitive DNA sequences in the course of protoplast and plant regeneration. Planta 194:306-310

Larkin PJ, Scowcroft WR (1981) Somaclonal variation - a novel source of variability from cell cultures for plant improvement. Theor Appl Genet 60:197-214

Lewis J, Bird A (1991) DNA methylation and chromatin structure. FEBS Lett 285:155-159

LoSchiavo F, Pitto L, Giuliano G, Torti G, Nuta-Ronchi V, Marazziti D, Vergara R, Orselli S, Terzi M (1989) DNA methylation of embryogenic carrot cell cultures and its variation as caused by mutation, differentiation, hormones and hypomethylating drugs. Theor Appl Genet 77:325-331

Matzke MA, Matzke AJM (1991) Differential inactivation and methylation of a transgene in plants by two suppressor loci containing homologous sequences. Plant Mol Biol 16:821-830

McClelland M, Nelson N (1985) The effect of site-specific methylation on restriction endonuclease digestion. Nucleic Acids Res 13:R201-R207

Messeguer R, Ganal MW, Steffens JC, Tanksley SD (1991) Characterization of the level, target sites and inheritance of cytosine methylation in tomato nuclear DNA. Plant Mol Biol 16:753-770

Meyer P, Niedenhof I, Ten Lohuis M (1994) Evidence for cytosine methylation of non-symmetrical sequences in transgenic Peturia hybrida. EMBO J 13:2084-2088

Müller E, Brown PTH, Hartke S, Lörz H (1990) DNA variation in tissue culture-derived rice plants. Theor Appl Genet 80:673-679

Ngernprasirtsiri J, Kobayashi H, Akazawa T (1988) DNA methylation occurred around lowly expressed genes of plastid DNA during tomato fruit development. Plant Physiol 88:16-20
Ngernprasirtsiri J, Chollet R, Kobayashi H, Sugiyama T, Akazawa $\mathrm{T}$ (1989) DNA methylation and the differential expression of $\mathrm{C} 4$ photosynthesis genes in mesophyll and bundle sheath cells of greening maize leaves. J Biol Chem 264:8241-8248

Quemada H, Roth EJ, Lark KG (1987) Changes in methylation of tissue cultured soybean cells detected by digestion with the restriction enzymes HpaII and MspI. Plant Cell Rep 6:63-66

Peschke VM, Phillips RL (1991) Activation of the maize transposable element suppressor-mutator (Spm) in tissue culture. Theor Appl Genet 82:121-129

Rus-Kortekaas W, Smulders MJM, Arens P, Vosman B (1994) Direct comparison of levels of genetic variation in tomato detected by a GACA-containing microsatellite probe and by random amplified polymorphic DNA. Genome 37:375-381

Sano H, Noguchi H, Sager R (1983) Characterization of DNA methyltransferases from bovine thymus cells. Eur J Biochem 135:181-185

Smulders MJM, W Rus-Kortekaas, LJW Gilissen (1995) Natural variation in patterns of polysomaty among individual tomato plants and their regenerated progeny. Plant Sci 106:129-139

Van den Bulk RW, Löffler HJM, Lindhout WH, Koornneef M (1990) Somaclonal variation in tomato: effect of explant source and comparison with chemical mutagenesis. Theor Appl Genet 80: $817-825$

Vanyushin BF, Kirnos MD (1988) DNA methylation in plants. Gene 74:117-121

Vosman B, Arens P, Rus-Kortekaas W, Smulders MJM (1992) Identification of highly polymorphic DNA regions in tomato. Theor Appl Genet 85:239-244.

Vyskot B, Gazdová B, Siroký J (1993) Methylation patterns of two repetitive DNA sequences in tobacco tissue cultures and their regenerants. Biol Plant 35:321-327

Watson JC, Kaufman LS, Thompson WF (1987) Developmental regulation of cytosine methylation in the nuclear ribosomal RNA genes of Pisum sativum. J Mol Biol 193:15-26 